\title{
On the Process of Understanding the Reading of Students with Mental Disabilities: An Examination of Teacher Practices
}

\author{
Abdurrahman Uyanık ${ }^{1}$, Cahit Nuri ${ }^{2}$, Hakan Sar1 ${ }^{3}$ \\ ${ }^{1}$ Necmettin Erbakan University, Ahmet Keleşoğlu Faculty of Education, Department of Special Education, Turkey. \\ ORCID ID: 0000-0002-2480-6290 \\ ${ }^{2}$ Cyprus International University, Faculty of Education, Department of Special Education, North Cyprus, Cyprus. \\ ORCID ID: 0000-0002-8926-2984 \\ ${ }^{3}$ Necmettin Erbakan University, Ahmet Keleşoğlu Faculty of Education, Department of Special Education, Turkey. \\ ORCID ID: 0000-0003-4528-8936 \\ Correspondence: Cahit Nuri, Cyprus International University, Faculty of Education, Department of Special \\ Education, North Cyprus, Cyprus.
}

Received: Nov. 16, $2020 \quad$ Accepted: Dec. 14, $2020 \quad$ Online Published: Dec. 16, 2020

doi:10.11114/jets.v9i1.5107 URL: https://doi.org/10.11114/jets.v9i1.5107

\begin{abstract}
This study aims to examine the teacher adaptations related to the stages of the reading process used in the process of understanding the reading of students with mental disabilities according to different variables. A descriptive survey model which is one of the quantitative research methods was used in the study. In 2018-2019, to ensure the research sample, reliability, and validity of the scale, 361 classroom teachers were gathered from 18 primary schools of Meray and Kartay districts of Konya province. It was applied to 93 more classroom teachers to provide a confirmatory factor analysis of the scale. After ensuring validity and reliability, it was applied to 99 special education teachers working in primary schools in Karatay, Meram, and Selcuklu districts of Konya province for descriptive analysis. Scores of male teachers are a little higher than female teachers in the scale of teacher practices related to the stages of the reading process. Graduate-level teachers, who have received training in the scale of teacher practices related to the stages of the reading process, score at the undergraduate level. Yet, the observed difference was not statistically significant in question.
\end{abstract}

Keywords: underdeveloped intelligence, reading, reading comprehension, mainstreaming, reading process, teacher applications

\section{Introduction}

\subsection{Introduce the Problem}

Reading is the process of interpreting and evaluating the letters read by the sensory organs by the brain (Ozbay, 2014). The five basic elements of reading include phonemic awareness, phonetic analysis, fluency, vocabulary development, reading comprehension (National Reading Panel - NRP, 2000). Phonemic awareness; the most important foundation in reading is the ability of students to use the relationship between sounds and symbols in their learning and language systems. Basic considerations in phonetic awareness encompass the skills of spelling awareness, separating the first sound in a word, combining sounds, and separating single sounds (Oakhill, Yuill \& Garnham, 2011). The phonetic analysis presents a strategy of finding unknown words through the application of a learned system (Bursuck \& Damer, 2007). The phonetic analysis helps the student understand the relationships between sounds and letters, gain alphabetic knowledge. Fluency is to read the reading text accurately, quickly, and meaningfully. Vocabulary is the teaching of visually recognized words. A large part of it develops depending on daily life experiences (Cetinkaya, 2018; Uysal \& Bilge, 2019).

According to Cuhadar (2012), for reading to occur, we must first see the word or letter. Visual symbols are detected by the eye and transmitted to the brain. As the eye reads the text, it advances by selecting words and waits between words. At this time, information is transmitted to the brain. This process of reading, which begins with a vision, is the physical dimension of reading. Sever (1997) describes the general qualities of the reading process as "reading is a process of communication, perception, learning, cognitive, affective, and kinetic-dimensional development." 


\subsection{Explore Importance of the Problem}

State Some factors are instrumental in gaining the ability to understand what students with mental disabilities are reading. These factors are collected in two groups. The first factor is the lack of students with characteristics that affect skills related to understanding. The second is the inability to apply teaching methods that enable the student to learn effectively. Of the factors affecting understanding, the most important is fluent reading. Readers who analyse text fluently without stopping on syllables focus more on meanings, hence understand what they analyse (Kanmaz, 2012; Gokbulut, 2018). For this reason, students must have the ability to analyse a text without spelling it before the education of understanding what they are reading.

Reading comprehension involves the before, during, and after reading stages of the reading process. Features of this stage;

a) Before-reading

1. Should have sufficient vocabulary.

2. Motivation must be provided.

3. Text format types should be noticed.

b) During-reading

1. Should be aware that they are reading by considering the reading comprehension.

2. Words, phrases, and sentences should be read correctly and fluently.

3. A connection must be established between sentences.

4. Questions about the text being read should be asked and these questions should be answered.

5. Background information must be invoked to understand the text.

6. Should be selective about reading and unread text.

7. Important and trivial points must be determined.

8. Visualization must be performed to understand the text.

9. Inferences should be made about the thought subject.

c) After-reading

1. Opinion on the text should be reported.

2. The text should be summarized.

3. The main idea must be determined.

4. A link must be made between the read information and new situations (Polloway et. al., 2014; Gokbulut, 2018).

Reading comprehension is crucial for both normal students and students with mental disabilities to demonstrate academic success. In the lectures, teachers should give wide coverage to understanding training (Ozmen, 2011). Besides, reading comprehension and fluent reading are related to each other (Bastug \& Akyol, 2012). Fluent reading consists of the student's reading speed, the correct reading of words and sentences, and the simultaneous display of skills in the reading process (Zarain, 2007). Fundamentally, the reading process aims to describe the system in a specific text. Reading is the activity of making sense of what is being read by associating words or phrases in the text within themselves, no matter what state, form, or structure (Uysal \& Bilge, 2019). In performing this activity, the reader also reveals the forms and methods of making sense of the text, which are revealed by poetics and text analysis theories. Yet, reading is not a situation that can be specified only by theories, but rather an individual activity that connects all theories. In short, reading and perceiving a text by the reader is not a phenomenon that can be explained by strict rules, but rather an active communication process (Akbayir, 2003).

One of the most important difficulties in reading comprehension research and teaching reading comprehension is the inability to reach a consensus in definitions related to reading comprehension. Although there are many definitions in this regard, there is debate about which of these definitions is better. Researchers can be said to agree among reading educators that reading comprehension is a multidimensional process (Klein, 1988; Uysal \& Bilge, 2019). Akyol, Çakıroglu \& Kuryer (2014) in their study it was concluded that for the development of the reading skills of the students having reading difficulty, construction of appropriate reading environment and implementation of enrichment reading programs can be effective.

Reading comprehension is the basis of academic education in schools. Teaching methods of reading comprehension are 
grouped in different ways in the field. One of these groupings is before-reading, during-reading and after reading applications. In the pre-reading phase, the student should try to be guided by the text they will read (Vaughn \& Klingner, 2004). The classroom teacher must first motivate the student when he enters the classroom. The teacher is very important in this motivation. The teacher should know the student with underdeveloped intelligence very well. Before reading is a conversation about the title, a conversation about the subject of the text, and an explanation of the passing concepts in the text. During-reading is understanding the information in the text and linking it (Guzel, 1998; Akcamete $\&$ Gokbulut, 2018).

\subsection{Relevant Scholarship}

Research on teacher practices conducted during reading comprehension activities for students with mental disabilities in our country is quite small when literature is researched. Only one study was found in our country (Guler, 2008). In these studies, student and teacher opinions on reading comprehension, as well as reading comprehension skills, were not discussed in detail. For all these reasons, by interviewing with the teachers of students with underdeveloped intelligence, what teachers read in the classroom, what they practice for the reading comprehension process during education were discussed.

\subsection{Research Questions}

This research aims to examine teacher practices related to the stages of the reading process that are used in reading comprehension for students with mental disabilities. Following this purpose an answer has been sought to the following questions;

1. Is the scale of teacher practices related to the stages of the reading process valid and reliable?

2. Does the practice of the stages of the reading process, used in the process of understanding what students are reading, differ according to the age of teachers?

3. Does the practice of the stages of the reading process, used in the process of understanding what students are reading, differ according to the gender of teachers?

4. Does the practice of the stages of the reading process, used in the process of understanding what students are reading, differ according to the professional seniority of teachers?

5. Does the practice of the stages of the reading process, used in the process of understanding what students are reading, differ according to the education level of teachers?

6. Does the practice of the stages of the reading process, used in the process of understanding what students are reading, differ according to the classroom size?

\section{Method}

\subsection{Research Model}

In this study, a descriptive survey model was used to determine "the practices used by special education teachers in their classroom in the process of understanding what students with underdeveloped intelligence are reading." Descriptive survey models are a model suitable for research aimed at describing an existing situation in the past or present as it is (Karasar, 2013). Research is a descriptive study in a survey model that aims to describe a situation that exists in the past or still as it exists. Practitioner classroom teachers, special education teachers, and teacher practices in the process of reading comprehension have been tried to be defined within their conditions and as is.

\subsection{Sample Group}

A stratified sampling method formed the sample of the research. The purpose of selecting this sample is to represent the sample in the amount of numbers of subgroups (layers) in the universe (Buyukozturk et al., 2012). Stratified sampling is used when there are substrates or subunits in a universe whose boundaries have been determined (Yıldırım \& Simsek, 2006). For this sample to be made, first of all, the universe is divided into sub-universes that have similarities in themselves in terms of a variable that is important for research. The number of subjects to be selected from each sub-universe is determined by the ratio of that sub-universe's share in the entire universe. Thus, the ability of the sample to be created to represent all subunits of the universe is guaranteed (Karasar, 2013). In the study, schools were selected first through sampling. Teachers who have similarities in themselves have been identified. In this way, it has been tried to ensure that it represents all the subunits of the universe. Classroom teachers and special education sub-classroom teachers were selected. The research took place in the 2018-2019 academic year, consisted of 361 classroom teachers in 18 primary schools located in Meram, Karatay, and Selcuk districts of Konya province. It was then applied to 93 classroom teachers for confirmatory factor analysis of the scale. A total of 453 classroom teachers were assumed to answer questions on the scale frankly and sincerely. For the collection of data, the necessary permission was obtained 
twice from the Konya Directorate of National Education through the Postgraduate Education and Research Institute of Cyprus International University. Information about participants is included.

Table 1. Information About Classroom Teachers

\begin{tabular}{lccc}
\hline $\begin{array}{c}\text { District } \\
\text { Name }\end{array}$ & $\begin{array}{c}\text { Number of } \\
\text { Schools }\end{array}$ & $\begin{array}{c}\text { Number of } \\
\text { Teachers }\end{array}$ & $\begin{array}{c}\text { Teachers Who Have } \\
\text { Responded }\end{array}$ \\
\hline Karatay & 10 & 312 & 250 \\
Meram & 8 & 246 & 203 \\
Toplam & 18 & 558 & 453 \\
\hline
\end{tabular}

A second sample was created in line with the main purpose of the research. In Table 1, 99 special education teachers serving in special lower classes in primary schools in Karatay, Meram, and Selcuklu districts of Konya province were applied to the "Teacher Information Form" and "Teacher Practice Scale Related to the Stages of the Reading Process". The responses were analysed.

Table 2. Special Education Teachers Information About the Participants

\begin{tabular}{cccc}
\hline $\begin{array}{c}\text { District } \\
\text { Name }\end{array}$ & $\begin{array}{c}\text { Number of } \\
\text { Schools }\end{array}$ & $\begin{array}{c}\text { Number of } \\
\text { Teachers }\end{array}$ & $\begin{array}{c}\text { Teachers Who Have } \\
\text { Responded }\end{array}$ \\
\hline Karatay & 11 & 32 & 30 \\
Meram & 11 & 24 & 22 \\
Selcuklu & 12 & 49 & 47 \\
Toplam & 34 & 105 & 99 \\
\hline
\end{tabular}

In Table 3., findings from frequency analysis on the distribution of teachers by socio-demographic characteristics included in the study were shown.

Table 3. Distribution of Teachers by Socio-Demographic Characteristics

\begin{tabular}{|c|c|c|}
\hline \multirow{2}{*}{\multicolumn{3}{|c|}{ Age Group }} \\
\hline & & \\
\hline 34 years and below & 26 & 26.26 \\
\hline Between 35-39 years & 275 & 27.27 \\
\hline 40 years and over & 46 & 46.46 \\
\hline \multicolumn{3}{|l|}{ Gender } \\
\hline Woman & 39 & 39.39 \\
\hline Man & 60 & 60.61 \\
\hline \multicolumn{3}{|l|}{ Level of Education } \\
\hline Undergraduate & 91 & 91.92 \\
\hline Postgraduate & 8 & 8.08 \\
\hline \multicolumn{3}{|l|}{ Professional Seniority } \\
\hline $1-5$ years & 12 & 12.12 \\
\hline $6-10$ years & 8 & 8.08 \\
\hline $11-15$ years & 26 & 26.26 \\
\hline 16 years and above & 53 & 53.54 \\
\hline \multicolumn{3}{|l|}{ Classroom Size } \\
\hline Between 1-4 & 10 & 10,10 \\
\hline Between 5-8 & 53 & 53,54 \\
\hline 9 and over & 36 & 36,36 \\
\hline
\end{tabular}

When Table 3, is examined, it can be seen that $26.26 \%$ of the teachers in the study were 34 years of age and under, $27.27 \%$ were $35-39$ years of age and $46.46 \%$ were in the 40 years age group and over and $39.39 \%$ of these were female and $60.61 \%$ were male. $91.92 \%$ of teachers received a bachelor's degree, $8.08 \%$ received a higher education, $12.12 \%$ of them had between $1-5$ years, $8.08 \%$ had between $6-10$ years, $26.26 \%$ had between $11-15$ years and $53.54 \%$ had 16 years or more professional seniority. $10.10 \%$ received a between $1-4,36.36 \%$ of them had between 9 and over, had between 5-8 or more classroom size.

\subsection{Data Collection Tools}

In the study, teacher opinions were tried to be determined during the students' reading comprehension process. Teacher practice scale form and teacher feedback form related to the stages of the reading process developed by the researcher were used. 


\subsubsection{Teacher Feedback Form}

In this form, the information about the teacher consists of items that define the teacher such as age, gender, professional seniority, classroom size, and the level of education of the teacher. Information about the teacher was obtained with the help of these questions. During the creation of this form, opinions were also taken from 3 experts specializing in special education areas, and the form was arranged according to these views. The form consists of six questions.

\subsubsection{The scale of Teacher Practices Related to The Stages of the Reading Process}

The scale of teacher practices related to the stages of the reading process was developed by researchers by scanning the field and taking expert opinions. An expert opinion was received from a professor, two associate professors, and an assistant professor in the field of special education. According to the feedback from them, 10 items were removed from the scale. A total of 25 items remained on the scale. A preliminary application was made to the 453 classroom teachers for their validity and reliability, and the validity and reliability of the scale were measured. The scale was then applied to 99 special education teachers who served in the special education subclass. After analysis, the scale was found to be one-dimensional. The teacher Practice Scale for the stages of the reading process is a Likert-type measurement tool that uses a five-way rating. Responses to the scale are scored as "absolutely disagree=1 point", "disagree=2 points", "undecided=3 points", "agree $=4$ points", "fully agree $=5$ points". The lowest score that can be taken from the scale is 25 , and the highest score is 125 . As a result of a validity-reliability study conducted by the researcher, it was determined that the scale is a one-dimensional structure and the Cronbach Alpha value is 0.982 . Details of the validity reliability study of the scale are presented in the results section.

\subsection{Data Collection}

Along with the description of subjects, give the mended size of the sample and number of individuals meant to be in each condition if separate conditions were used. State whether the achieved sample differed in known ways from the target population. Conclusions and interpretations should not go beyond what the sample would warrant. Data of the research was collected in teachers' schools during the second semester of the 2018-2019 academic year. Work in schools was initiated and terminated at the same time. The scale was applied to all aspiring teachers who had inclusive students in their classes.

1. First, the researcher distributed the form to teachers,

2. When distributing the form, attention was paid to selecting teachers who have inclusive students in their class,

3. The purpose of the research is explained,

4. They were asked to answer questions frankly and sincerely.

5. It is explained how they should fill the scale,

6. Teachers are given a certain amount of time,

7. At the end of this period, interview forms of teachers who answered the items in the form were collected immediately,

8. Those who want to answer the articles later have been asked to submit the form to the school administration,

9. The Form was received from the school administration within three days at the latest,

10. Forms distributed and delivered at school are noted in the notebook,

11. Interview forms are numbered in order,

12. According to this given number, the file created in Excel is processed,

13. All these procedures were performed in four weeks at each school.

After the validity and reliability of the scale were ensured, 99 special education teachers (Table 4) from a total of 105 special education teachers, who worked in thirty-four primary schools in Karatay, Meram, and Selcuklu districts of Konya province, responded to the items on the scale. Application and analysis of the scale for special education teachers were completed in one month.

\subsection{Analysis of the Data}

Include Statistical Package for Social Sciences (SPSS) 24.0 software and IBM AMOS 24.0 software were used to analyse the data collected in this study from a statistical point of view. As part of the validity-reliability study of the scale of teacher applications related to the stages of the reading process; exploratory factor analysis, confirmatory factor analysis, Cronbach alpha test, Split-Half test, total item correlation analysis was applied. As part of the study's descriptive dimension, the socio-demographic characteristics of teachers were determined by frequency analysis, and 
the average and standard deviation values for their responses to the Scale of Teacher Practices Related to the Stages of the Reading Process were shown. Descriptive statistics of the scores teachers received from the Teacher Practice Scale for the Stages of the Reading Process are shown. The normal distribution of scale scores was studied using the Kolmogorov-Smirnov and Shapiro-Wilk tests to determine the test statistics that will be used to compare Teacher Practice Scale Scores for the Stages of the Reading Process according to the socio-demographic characteristics of teachers. As a result of the normality tests, it was found that the scale scores did not show normal distribution, and non-parametric test statistics were used. Accordingly, the Kruskal-Wallis $\mathrm{H}$ test was used to compare the scores of the Teacher Practices Scale for the Stages of the Reading Process according to the age group, professional seniority, and the number of students in the class they work in, and the Mann-Whitney $U$ test was used to compare the scale scores according to their gender, educational status and the type of disability of their students.

\section{Results}

\subsection{Results About Structure Validity Analysis of Teacher Practice Scale Related to The Stages of the Reading Process}

Exploratory factor analysis and confirmatory factor analysis were applied to examine to construct validity of the teacher practice scale related to the stages of the reading process, and the results of the applied factor analysis are shown below;

\subsubsection{Exploratory Factor Analysis}

Exploratory factor analysis was applied to determine the factor structure of the scale. Exploratory factor analysis is a method of factor analysis used to create new factors independent of each other, provided that they are less than the correlation matrix or $\mathrm{K}$ variables associated with them using the covariance matrix of the data obtained utilizing a measurement tool (Ozdamar, 2002). Before switching to exploratory factor analysis, it was examined whether the data set provided the necessary assumptions for applying factor analysis. In this context, teacher practices related to the stages of the reading process, the draft form of the scale examined and determined that it adapted to the multivariate normal distribution and Kaiser-Meyer-Olkin (KMO) coefficient which is used in determining the eligibility to do exploratory and Barlett's tests for sphericity was applied.

Table 4. Teacher Practice Scale KMO and Bartlett Test Results for Stages of Reading Process

\begin{tabular}{ccc}
\hline & & Values \\
\hline Kaiser-Mayer-Olkin & KMO Coefficient & 0.978 \\
& Chi-Square Value & 13153.148 \\
Bartlett Testi & Degree of Freedom & 300 \\
& $\mathrm{P}$ & 0.000 \\
\hline
\end{tabular}

Table 4, when examined, it was found that the Kaiser-Meyer-Olkin coefficient of the teacher practice scale related to the stages of the reading process was 0.978 . The KMO coefficient gives information about whether the data matrix is suitable for factor analysis, the suitability of the data structure for factor subtraction. For factorization, KMO is expected to be higher than 0.60 . The Barlett test examines whether there is a relationship between variables based on correlations (Buyukozturk, 2009). Looking at the results of Bartlett's Test of Sphericity, it was determined that the calculated square value of the test was 13153,148 and that this value was statistically significant $(\mathrm{p}<0.05)$. According to these results, the Scale of Teacher Practices Related to the Stages of the Reading Process was found to be suitable for exploratory factor analysis.

In Table 5. eigenvalues obtained as a result of the final exploratory factor analysis applied to the Scale of Teacher Practices Related to the Stages of the Reading Process, the variances they explain are shown. The principal component analysis method was used in explaining factor analysis to determine the factor structure of the Scale of Teacher Practices Related to the Stages of the Reading Process and varimax rotation was applied to the data set. 
Table 5. Exploratory Factor Analysis Results of Teacher Practice Scale Related to The Stages of the Reading Process

\begin{tabular}{|c|c|c|c|c|c|c|}
\hline \multirow[t]{2}{*}{ Substance } & \multicolumn{3}{|c|}{ Eigenvalues } & \multicolumn{3}{|c|}{ Sum of Squares of Loads } \\
\hline & Total & Variance $(\%)$ & Cum. Var. \% & Total & Variance $(\%)$ & Cum. Var. \% \\
\hline 1 & 17.55 & 70.19 & 70.19 & 17.55 & 70.19 & 70.19 \\
\hline 2 & 1.12 & 4.50 & 74.69 & & & \\
\hline 3 & 0.75 & 3.02 & 77.71 & & & \\
\hline 4 & 0.55 & 2.18 & 79.89 & & & \\
\hline 5 & 0.45 & 1.81 & 81.70 & & & \\
\hline 6 & 0.43 & 1.72 & 83.42 & & & \\
\hline 7 & 0.35 & 1.41 & 84.84 & & & \\
\hline 8 & 0.34 & 1.34 & 86.18 & & & \\
\hline 9 & 0.32 & 1.27 & 87.45 & & & \\
\hline 10 & 0.32 & 1.26 & 88.71 & & & \\
\hline 11 & 0.30 & 1.21 & 89.92 & & & \\
\hline 12 & 0.26 & 1.05 & 90.97 & & & \\
\hline 13 & 0.25 & 1.01 & 91.99 & & & \\
\hline 14 & 0.23 & 0.90 & 92.89 & & & \\
\hline 15 & 0.22 & 0.87 & 93.76 & & & \\
\hline 16 & 0.21 & 0.83 & 94.59 & & & \\
\hline 17 & 0.19 & 0.77 & 95.35 & & & \\
\hline 18 & 0.19 & 0.74 & 96.10 & & & \\
\hline 19 & 0.18 & 0.71 & 96.81 & & & \\
\hline 20 & 0.16 & 0.63 & 97.44 & & & \\
\hline 21 & 0.15 & 0.61 & 98.05 & & & \\
\hline 22 & 0.14 & 0.58 & 98.62 & & & \\
\hline 23 & 0.13 & 0.50 & 99.13 & & & \\
\hline 24 & 0.11 & 0.45 & 99.58 & & & \\
\hline 25 & 0.11 & 0.42 & 100.00 & & & \\
\hline
\end{tabular}

When Table 5., is examined, according to Tabachnick \& Fidell (2013), the factor load of an item on a factor is expected to be at least 0.30 . Accordingly, the items with a factor load of less than 0.30 in the 35 -item draft scale were removed from the scale, and the 25 -item form of the scale emerged. It was seen that there are two factors with an eigenvalue above 1 of the Teacher Practices Scale Regarding the Stages of the Reading Process. Since the variance explained by two factors with an eigenvalue above 1 is very low and the single factor structure explains $\% 70.19$ of the total variance, it was determined that the scale has a single factor structure. 
Table 6. Factor Load Values of the Teacher Practices Scale Related to the Stages of the Reading Process

\begin{tabular}{|c|c|}
\hline Items & $\begin{array}{l}\text { Factor } \\
\text { Load }\end{array}$ \\
\hline 1. Before reading, I activate my student's knowledge of the subject. & 0.86 \\
\hline 2. Before reading, I pre-prepare my student to understand each part of the text. & 0.84 \\
\hline 3. Before reading, I motivate my student to be willing to read the text. & 0.84 \\
\hline 4. Before reading, I help my student to find the answers to the questions of where? and how? & 0.85 \\
\hline $\begin{array}{l}\text { 5. I enable students to make connections between words they know the meaning of and the words they do } \\
\text { not know. }\end{array}$ & 0.85 \\
\hline 6. I'll get my student to talk about the title before reading. & 0.83 \\
\hline 7. Before reading, I draw my student's attention to new words. & 0.84 \\
\hline 8. During reading, I make my student understand the author's purpose. & 0.82 \\
\hline 9. During reading, I help my student understand the structure and logical layout of the text. & 0.85 \\
\hline 10. During reading, I help my student draw conclusions and make judgements. & 0.83 \\
\hline 11. During reading, I help my student draw the main idea of the paragraphs and the whole text. & 0.86 \\
\hline 12. During reading, I enable my student to search for specific information in the text. & 0.83 \\
\hline $\begin{array}{l}\text { 13. During reading, I make sure that my student finds the answers to the given questions before starting to } \\
\text { read the text. }\end{array}$ & 0.85 \\
\hline 14. During reading, I get my student to complete the diagrams and maps given about the text. & 0.82 \\
\hline 15. During reading, I make sure that my student takes notes about the message given in the text. & 0.77 \\
\hline 16. After reading, I allow my student to conduct a deeper analysis of the text. & 0.76 \\
\hline 17. After reading, I get my student to combine the inferences from the text. & 0.83 \\
\hline 18. After reading, I'll have my student summarize what he/she's reading. & 0.85 \\
\hline $\begin{array}{l}\text { 19. After reading, I make sure that my student combines the information in the text with the previous } \\
\text { knowledge. }\end{array}$ & 0.87 \\
\hline 20. After reading, I have my student evaluate the information learned. & 0.89 \\
\hline $\begin{array}{l}\text { 21. After reading, I ask my student to evaluate the usability of the information learned from the text in real } \\
\text { life. }\end{array}$ & 0.87 \\
\hline $\begin{array}{l}\text { 22. After reading, I have my student use the new words and structures learned from the text in their } \\
\text { writing activities. }\end{array}$ & 0.85 \\
\hline 23. After reading, I answer my student's questions about the text. & 0.83 \\
\hline 24. After reading, I make sure that my student underlines the highlights in the text. & 0.83 \\
\hline 25. After reading, I discuss various parts of the text with my student. & 0.83 \\
\hline
\end{tabular}

In Table 6, it was observed that the factor loads of items included in the Teacher Practice Scale Related to the Stages of the Reading Process ranged from 0.76 to 0.89 . According to these results, Teacher Practices Related to the Stages of the Reading Process showed that the scale consists of items with positive factor loads in a single-factor structure. 


\subsubsection{Confirmatory Factor Analysis}

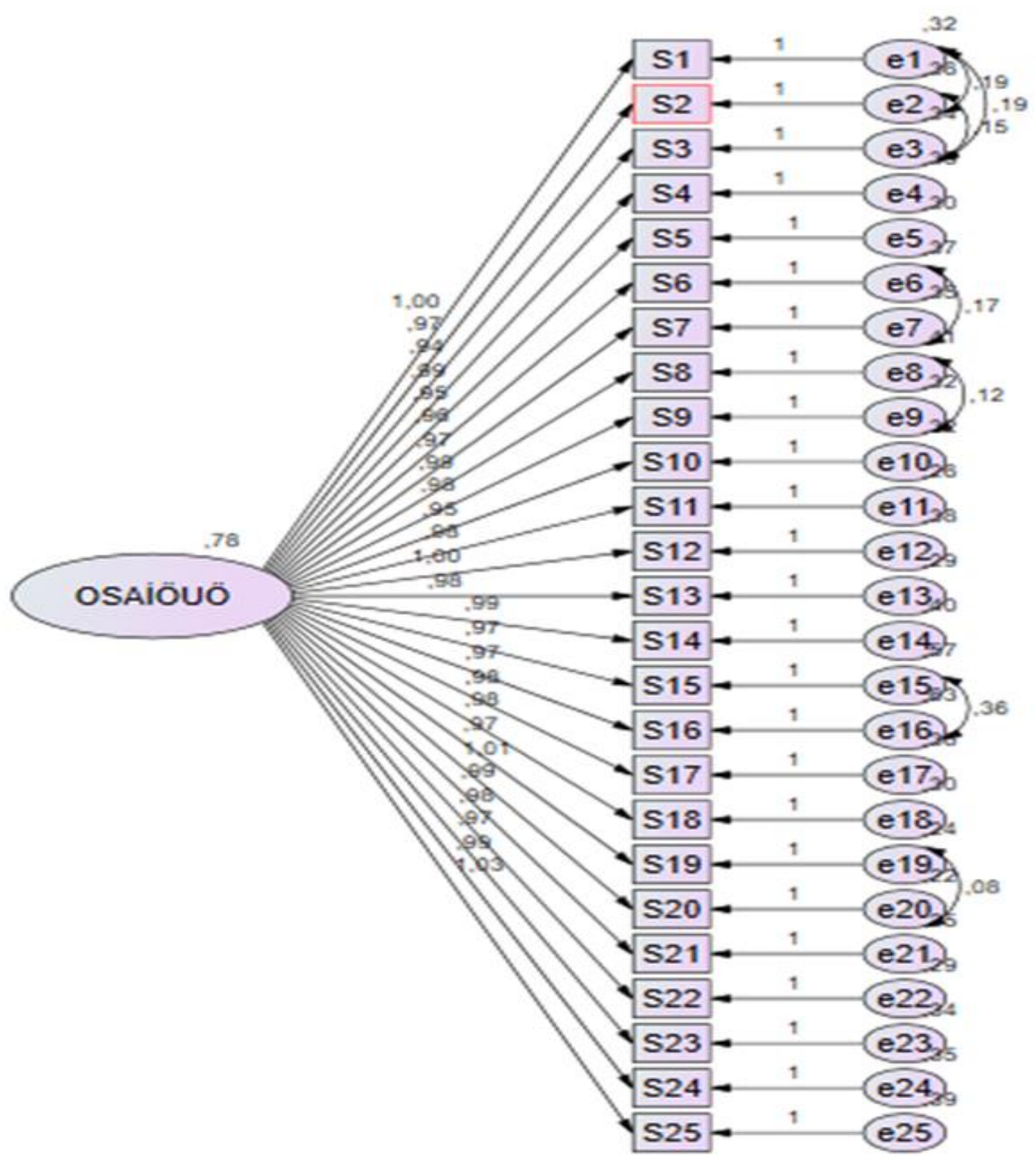

Figure 1. Confirmatory Factor Analysis of Teacher Practice Scale for the Stages of the Reading Process Path Diagram

After determining the factor structure of the Teacher Practice Scale Related to the Stages of the Reading Process, the suitability of the factor structure of the scale confirmed, and confirmatory factor analysis was applied in the study of determining the relationships between factors. Confirmatory factor analysis is an extension of exploratory factor analysis. Exploratory factor analysis is used when explaining the factor structure of a measurement tool whereas confirmatory factor analysis is used to test whether the relationship between AFA and pre-determined factors is sufficient, which factors are related, the states of factors being independent of each other, and whether the pre-determined factors are sufficient to explain the established model (Erkorkmaz, Etikan, Ozdamar and Sanisoglu, 2013).

Confirmatory Factor Analysis path diagram of the Teacher Practice Scale for the Stages of the Reading Process shown in Figure 1. was given, and it was found that the scale of the single-factor and 25-item scale determined by the exploratory factor analysis had a good fit without removing any items.

Table 6. The goodness of Fit Indexes of Teacher Practice Scale Related to The Stages of the Reading Process

\begin{tabular}{llll}
\hline Index & Value & Limit Value & Fit \\
\hline$\chi^{\mathbf{2} / \mathbf{s d}}$ & 3.708 & $3-5$ & Acceptable \\
Goodness of Fit Index (GFI) & 0.837 & $0.90-0.95$ & - \\
Normed Fit Index (NFI) & 0.928 & $0.90-0.95$ & Acceptable \\
Comparative Fit Index (CFI) & 0.946 & $0.90-0.95$ & Acceptable \\
Root Mean Square Error of Approximation (RMSEA) & 0.077 & $0.5-0.8$ & Acceptable \\
\hline
\end{tabular}


When confirmatory factor analysis the goodness of fit index values of Teacher Practice Scale for the Stages of the Reading Process given in Table 6 . Were examined, $\chi^{2} /$ sd was found to be 3,708, indicating that the teacher practice scale for the stages of the reading process has an acceptable alignment from the point of view of $\chi^{2} / \mathrm{sd}$. According to Kline (2005), the fact that $\chi^{2} / \mathrm{sd}$ is below 3 shows that it is a perfect fit, while the fact that it is between 3 and 5 shows that it is an acceptable fit. The fact that the Goodness of Fit Index (GFI) is between 0.95 and 1.00 indicates the existence of perfect harmony, while the fact that it is in the range of 0.90 and 0.95 indicates the existence of an acceptable harmony (Sumer, 2000). The goodness of Fit Index (GFI) determined for the Teacher Practice Scale Related to the Stages of the Reading Process was found to be 0.837 , and the goodness of fit index value was determined to be poor. The Normed Fit Index (NFI) value of the scale was found to be 0.940 according to the results of the Teacher Practice Scale Confirmatory Factor Analysis of the Stages of the Reading Process. According to Tabachnick and Fidell (2001), the limit value for the Normed Fit Index is between 0.90 and 1.00. The NFI value is expected to be between the specified limit values, which indicates acceptable compliance. Of the critical values set for the comparative Fit Index (CFI), the range $0.95-1.00$ indicates the existence of good compliance, while the range $0.90-0.95$ indicates the existence of acceptable compliance (Tabachnick \& Fidell, 2001). The Comparative Fit Index value set for the Teacher Practice Scale for the Stages of the Reading Process is 0.946, which indicates that the Teacher Practice Scale for the Stages of the Reading Process has acceptable compliance in terms of the Comparative Fit Index. Root Mean Square Error of Approximation (RMSEA) value of the scale was 0.077. According to Brown (2006), the fact that the RMSEA value is between 0.00-0.05 indicates a perfect fit, and the fact that it is between 0.05-0.08 indicates an acceptable fit. Accordingly, it was found that the Scale of Teacher Practices Related to the Stages of the Reading Process has an acceptable alignment from the point of view of RMSEA. As a result of the confirmatory factor analysis, it was determined that all goodness of fit indexes other than GFI of the Teacher Practice Scale Related to the Stages of the Reading Process are appropriate and that the structure validity of the scale is ensured.

\subsubsection{Reliability Analysis of Teacher Practice Scale Related to the Stages of the Reading Process}

To examine the reliability of the Teacher Practice Scale for the Stages of the Reading Process, the Cronbach Alpha test and the Split-Half test was performed respectively, and the total item correlations of the scale were studied.

Table 7. Cronbach Alpha and Split Half Test Results of Teacher Practice Scale for Stages of Reading Process

\begin{tabular}{lll}
\hline Cronbach Alpha Test & & 0.982 \\
\hline & I. half Cronbach Alfa(13 Items) & 0.970 \\
& II. half Cronbach Alfa(12 Items) & 0.965 \\
\cline { 2 - 3 } Split Half Test & Correlation between halves & 0.922 \\
\cline { 2 - 3 } & Spearman-Brown & 0.959 \\
& GuttmanSplit-Half & 0.958 \\
\hline
\end{tabular}

When Table 7. is examined, it was found that the Cronbach Alpha coefficient of the Cronbach Alpha test results of the Teacher Practice Scale Related to the Stages of the Reading Process was 0.982. According to Buyukozturk (2012), the measurement tool shows that if the Cronbach Alpha reliability coefficient is above 0.70, it is reliable. In addition to the Cronbach Alpha test of the scale, a split-in-half test was applied and it was determined that the Cronbach Alpha coefficient of the first half of the scale was 0.970 , and the coefficient of the second half was 0.965 . It was determined that the correlation coefficient between halves was an extremely high number, such as 0.922 , and the Spearman-Brown coefficient was 0.959 and the Guttmansplit-Half coefficient was 0.958 . 
Table 8. Total Item Correlations of the Teacher Practices Scale Related to the Stages of the Reading Process

\section{Items}

Factor Load

1. Before reading, I activate my student's knowledge of the subject.

2. Before reading, I pre-prepare my student to understand each part of the text.

3. Before reading, I motivate my student to be willing to read the text.

4. Before reading, I help my student to find the answers to the questions of where? and how?

5. I enable students to make connections between words they know the meaning of and the words they do not know.

6. I'll get my student to talk about the title before reading.

7. Before reading, I draw my student's attention to new words.

8. During reading, I make my student understand the author's purpose.

9. During reading, I help my student understand the structure and logical layout of the text.

10. During reading, I help my student draw conclusions and make judgments.

11. During reading, I help my student draw the main idea of the paragraphs and the whole text.

12. During reading, I enable my student to search for specific information in the text.

13. During reading, I make sure that my student finds the answers to the given questions before starting to read the text.

14. During reading, I get my student to complete the diagrams and maps given about the text.

15. During reading, I make sure that my student takes notes about the message given in the text.

16. After reading, I allow my student to conduct a deeper analysis of the text.

17. After reading, I get my student to combine the inferences from the text.

18. After reading, I'll have my student summarize what he/she's reading.

19. After reading, I make sure that my student combines the information in the text with the previous knowledge.

20. After reading, I have my student evaluate the information learned.

21. After reading, I ask my student to evaluate the usability of the information learned from the text in real life.

22. After reading, I have my student use the new words and structures learned from the text in their writing activities.

23. After reading, I answer my student's questions about the text.

24. After reading, I make sure that my student underlines the highlights in the text.

25. After reading, I discuss various parts of the text with my student.

When examining the total item correlations of the Teacher Practice Scale Related to the Stages of the Reading Process given in Table 8., it was found that the correlations of the substances contained in the scale with the total were high and ranged from 0.74 to 0.87 . It was determined that the item with the highest total item correlation is " 20 . After reading, I have my student evaluate the information learned." the item with the lowest correlation with the total is "16. After reading, I allow my student to conduct a deeper analysis of the text." According to the results of the validity-reliability study given above, it was found that the scale of Teacher Practices Related to the Stages of the Reading Process ensures the validity of the structure and is similar to the original scale, and the reliability values are extremely good. Accordingly, it has been determined that the Scale of Teacher Practices Related to the Stages of the Reading Process is a valid and reliable measurement tool. 


\subsection{Findings on Teacher Practices Related to The Stages of the Reading Process of Teachers}

Table 9. Average and Standard Deviation of Teachers' Responses to the Scale of Teacher Practices Regarding the Stages of the Reading Process

\begin{tabular}{lc}
\hline Item & $\overline{\boldsymbol{x}} \pm \mathbf{S}$ \\
\hline 1. Before reading, I activate my student's knowledge of the subject. & $3.90 \pm 1.3$ \\
2. Before reading, I pre-prepare my student to understand each part of the text. & 5 \\
& $3.85 \pm 1.2$ \\
3. Before reading, I motivate my student to be willing to read the text. & 6 \\
4. Before reading, I help my student to find the answers to the question of where? And how? & 1 \\
a. & $3.88 \pm 1.3$
\end{tabular}

5. I enable students to make connections between words they know the meaning of and the words they do not $3.88 \pm 1.2$ know.

6. I'll get my student to talk about the title before reading.

7. Before reading, I draw my student's attention to new words.

8. During reading, I make my student understand the author's purpose.

9. During reading, I help my student understand the structure and logical layout of the text.

10. During reading, I help my student draw conclusions and make judgements.

11. During reading, I help my student draw the main idea of the paragraphs and the whole text.

12. During reading, I enable my student to search for specific information in the text.

$3.66 \pm 1.2$

13. During reading, I make sure that my student finds the answers to the given questions before starting to read the text.

$3.81 \pm 1.2$

14. During reading, I get my student to complete the diagrams and maps given about the text.

$3.76 \pm 1.2$

15. During reading, I make sure that my student takes notes about the message given in the text.

16. After reading, I allow my student to conduct a deeper analysis of the text.

17. After reading, I get my student to combine the inferences from the text.

18. After reading, I'll have my student summarize what he/she's reading

19. After reading, I make sure that my student combines the information in the text with the previous knowledge.

$3.90 \pm 1,2$

20. After reading, I have my student evaluate the information learned.

21. After reading, I ask my student to evaluate the usability of the information learned from the text in real life.

22. After reading, I have my student use the new words and structures learned from the text in their writing activities.

23. After reading, I answer my student's questions about the text.

24. After reading, I make sure that my student underlines the highlights in the text. 
In Table 9. average and standard deviation values regarding teachers ' responses to the Scale of Teacher Practices Related to the Stages of the Reading Process were shown. When Table 9., it was determined that the teachers included in the study responded to all the items in general as "I agree" on the Scale of Teacher Practices Related to the Stages of the Reading Process. The item that teachers strongly agreed is " 10. During reading, I help my student draw conclusions and make judgments." whereas their strongly disagreed item is "16. After reading, I allow my student to conduct a deeper analysis of the text."

Table 10. Total Scores of Teachers from The Scale Of Teacher Practices Related To The Stages Of The Reading Process

\begin{tabular}{lllllll}
\hline & $\mathrm{n}$ & $\overline{\boldsymbol{x}}$ & $\mathrm{s}$ & $\mathrm{M}$ & Bottom Top \\
\hline $\begin{array}{l}\text { Scale of Strategies } \\
\text { Related to the Stages of Reading Process }\end{array}$ & 99 & 94.73 & 26.58 & 100 & 25 & 125
\end{tabular}

In Table 10, descriptive statistics are given in the form of average, standard deviation, median, the lowest and highest value for the total scores that teachers received from the Scale of Teacher Practices Related to the Stages of the Reading Process When Table 10. examined, it is determined that the teachers who were involved in the research, received $\overline{\boldsymbol{x}}$ $=94,73 \pm 26,58$ points from the Scale of Teacher Practices Related to the Stages of the Reading Process. It was found that the median value for the scores obtained was 100, the highest score obtained from the Scale of Teacher Practices Related to the Stages of the Reading Process was 125 and the lowest score was 25.

Table 11. Comparison of Teachers' Total Scores from the Teacher Practices Scale Related to the Stages of the Reading Process According to Age Group

\begin{tabular}{cccccccc}
\hline Age Group & $\mathrm{n}$ & $\overline{\boldsymbol{x}}$ & $\mathrm{s}$ & $\mathrm{M}$ & Mean Rank & $\chi^{2}$ & $\mathrm{p}$ \\
\hline 34 years and below & 26 & 94.65 & 28.25 & 102.00 & 50.56 & & \\
Between 35-39 years & 27 & 98.11 & 22.68 & 100.00 & 51.91 & 0.244 & 0.85 \\
40 years and over & 46 & 92.78 & 28.07 & 99.00 & 48.57 & &
\end{tabular}

Table 11, shows the results of the Kruskal-Wallis H test applied to compare the total scores of the teachers included in the study according to the age group from the Teacher Practices Scale Related to the Stages of the Reading Process. According to Table 11, the teachers in the age group 34 and under who participated in the study got $\overline{\boldsymbol{x}}=94.65 \pm 28.25$ points from the Teacher Practices Scale Related to the Stages of the Reading Process, teachers in the 35-39 age group got $\overline{\boldsymbol{x}}=98.11 \pm 22.68$ points and teachers in the age group of 40 and over got a score of $\overline{\boldsymbol{x}}=92.78 \pm 28.07$. It was determined that the difference between the scores of the teachers included in the study from the Teacher Practices Scale Related to the Stages of the Reading Process according to the age group was not statistically significant ( $>0.05$ ). Although the scores of the Teachers' Practices Scale Related to the Stages of the Reading Process of teachers between the ages of 35-39 are higher than those of other age groups, the difference is not statistically significant. Regardless of age groups, students' scores on the Scale of Teacher Practices Related to the Stages of the Reading Process appear to be close.

Table 12. Comparison of Teachers' Total Scores from the Teacher Practices Scale Related to the Stages of the Reading Process According to their Gender

\begin{tabular}{ccccccccc}
\hline Gender & $\mathrm{n}$ & $\overline{\boldsymbol{x}}$ & $\mathrm{s}$ & $\mathrm{M}$ & Mean Rank & Rank Sum & $\mathrm{Z}$ & $\mathrm{p}$ \\
\hline Woman & 39 & 93.31 & 25.14 & 98.00 & 46.85 & 1827.00 & \multirow{2}{*}{0.881} & \multirow{2}{*}{0.378} \\
Man & 60 & 95.65 & 27.65 & 100.50 & 52.05 & 3123.00 & & \\
\hline
\end{tabular}

In Table 12, the results obtained from the Mann-Whitney U test on the comparison of the total scores of the teachers included in the study from the Teacher Practices Scale Related to the Stages of the Reading Process according to their gender are given. It was determined that female teachers participating in the study received $\overline{\boldsymbol{x}}=93.31 \pm 25.14$ points from the Scale of Teacher Practices Related to the Stages of the Reading Process, and male teachers received $\overline{\boldsymbol{x}}$ $=95.65 \pm 27.65$ points. It was observed that there was no statistically significant difference between the scores of the teachers included in the study from the Teacher Practices Scale Related to the Stages of the Reading Process according to their gender $(p>0.05)$. Although male teachers' scores on the scale of teacher practices related to the stages of the reading process are slightly higher than female teachers, they are not statistically significant. 
Table 13. Comparison of Teachers' Total Scores from the Teacher Practices Scale Related to the Stages of the Reading Process According to their Level of Education

\begin{tabular}{ccccccccc}
\hline Level of Education & $\mathrm{n}$ & $\overline{\boldsymbol{x}}$ & $\mathrm{s}$ & $\mathrm{M}$ & Mean Rank & Rank Sum & $\mathrm{Z}$ & $\mathrm{p}$ \\
\hline Undergraduate & 91 & 93.76 & 27.23 & 99.00 & 49.24 & 4480.50 & -0.893 & 0.372 \\
Postgraduate & 8 & 105.75 & 14.44 & 109.00 & 58.69 & 469.50 & & \\
\hline
\end{tabular}

The results of the Mann-Whitney U test regarding the comparison of the total scores of the teachers included in the study from the Teacher Practices Scale Related to the Stages of the Reading Process according to their education level are shown in Table 13. When Table 13. was examined, it was determined that teachers who received undergraduate education got $\overline{\boldsymbol{x}}=93.76 \pm 27.23$ points from the Teacher Practices Scale Related the Stages of the Reading Process, while teachers who received graduate education got $\overline{\boldsymbol{x}}=105.75 \pm 14.44$ points. It was determined that the difference between the scores of the teachers who received education at the undergraduate and graduate level from the Teacher Practices Scale Related to the Stages of the Reading Process was not statistically significant ( $>0.05$ ). Although the scores of the teachers who received graduate education were found to be higher than the teachers with undergraduate education in the Scale of Teacher Practices Related to the Stages of Reading Process, the difference was not statistically significant.

Table 14. Comparison of Teachers' Total Scores from the Teacher Practices Scale Related to the Stages of the Reading Process According to their Professional Seniority

\begin{tabular}{cccccccc}
\hline Professional Seniority & $\mathrm{n}$ & $\overline{\boldsymbol{x}}$ & $\mathrm{s}$ & $\mathrm{M}$ & Mean Rank & $\chi^{2}$ & $\mathrm{p}$ \\
\hline 1-5 year(s) & 12 & 95.42 & 33.73 & 107.50 & 54.13 & & \\
6-10 years & 8 & 98.13 & 12.10 & 99.00 & 47.25 & \multirow{2}{*}{0.349} & 0.951 \\
11-15 years & 26 & 94.08 & 26.56 & 97.50 & 49.06 & & \\
16 years and over & 53 & 94.38 & 27.02 & 100.00 & 49.94 & &
\end{tabular}

In Table 14, the results of the Kruskal-Wallis $\mathrm{H}$ test made for the comparison of the total scores obtained from the Teacher Practices Scale Related to the Stages of the Reading Process according to the professional seniority of the teachers included in the study are given. When Table 14 is examined, it is seen that teachers who have between 1-5 years of professional seniority got $\overline{\boldsymbol{x}}=95.42 \pm 33.73$ points, teachers who have 6-10 years of professional seniority got $\overline{\boldsymbol{x}}=98.13 \pm 12.10$ points, teachers who have between $11-15$ years of professional seniority got $\overline{\boldsymbol{x}}=94.08 \pm 26.56$ points and teachers who have 16 years and over of professional seniority got $\overline{\boldsymbol{x}}=94.38 \pm 27.02$ points from Teacher Practices Scale Related to the Stages of Reading Process. According to the professional seniority of teachers, it was found that the difference between teachers' scores on the Teacher Practice Scale Related to the Stages of the Reading Process was not statistically significant $(p>0.05)$. Although the scores of teachers with professional seniority of 6-10 years from the Teacher Practices Scale Regarding the Stages of the Reading Process are higher than the other teachers, this difference is not statistically significant. Regardless of the professional seniority of the teachers, it was observed that they got similar scores from the Teacher Practices Scale Related to the Stages of the Reading Process.

Table 15. Comparison of Teachers' Total Scores from the Teacher Practices Scale Related to the Stages of the Reading Process According to the Classroom Size

\begin{tabular}{lccccccc}
\hline Classroom Size & $\mathrm{n}$ & $\overline{\boldsymbol{x}}$ & $\mathrm{s}$ & $\mathrm{M}$ & Mean Rank & $\chi^{2}$ & $\mathrm{p}$ \\
\hline Between 1-4 & 10 & 104.30 & 15.71 & 103.00 & 57.65 & & \\
Between 5-8 & 53 & 88.87 & 30.15 & 96.00 & 44.79 & 3.795 & 0.150 \\
9 and over & 36 & 100.69 & 21.20 & 100.50 & 55.54 & & \\
\hline
\end{tabular}

Table 15. shows the results of the Kruskal-Wallis $\mathrm{H}$ test conducted to compare the total scores of the teachers included in the study from the Teacher Practices Scale Regarding the Stages of the Reading Process according to the class size they work. Teachers whose class size is between 1 and 4 students, received $\overline{\boldsymbol{x}}=104.30 \pm 15.71$ points from the Teacher Practices Scale Related to the Stages of the Reading Process, those who have between 5-8 students got $\overline{\boldsymbol{x}}=88.87 \pm$ 30.15 points and teachers who work in classes with 9 students and above got $\overline{\boldsymbol{x}}=100.69 \pm 21.20$ points. It was observed that there was no statistically significant difference between the total scores of teachers who were included in the study of the Scale of Teacher Practices Related to the Stages of the Reading Process according to the classroom size in which they work ( $>0.05)$. Teachers with a classroom size of 5-8 students scored lower on the Scale of Teacher Practices Related to the Stages of the Reading Process than other teachers, yet this difference is not statistically significant. 


\section{Conclusion and Discussion}

This study aims to examine the effectiveness of practices related to the stages of the reading process of special education teachers working with students with mental disabilities. Based on the findings obtained within the framework of this goal, the discussion was presented according to the sub-problems. It has been discussed by considering the results obtained for solving the sub-problems of the research and the results of the studies conducted in the field.

Exploratory factor analysis and confirmatory factor analysis were applied to examine the construct validity of the teacher practices scale related to the stages of the reading process, which is the first sub-problem of the study, the adaptation of the draft form of the teacher practices scale regarding the stages of the reading process to the multivariate normal distribution was examined and it adapted to the multivariate normal distribution. It has been determined. As a result of the Kaiser-Mayer-Olkin (KMO) coefficient and Bartlett's sphericity tests, which are used to determine its suitability to make an exploratory factor, it was seen that the Kaiser-Mayer-Olkin coefficient of the teacher practices scale related to the stages of the reading process was 0.978. Looking at the results of Bartlett's Test of Sphericity, it was determined that the calculated chi-square value of the test and the value of this was statistically significant $(\mathrm{p}<0.05)$. According to these results, the Scale of Teacher Practices Related to the Stages of the Reading Process was found to be suitable for exploratory factor analysis. They applied KMO and Bartlett's Kaiser-Mayer-Olkin tests in the Self-Directed Learning Test developed by Lee and Kang for young children and found that Bartlett's Kaiser-Mayer-Olkin coefficient was .946 and this value determined to be statistically significant. The results found are parallel with the scale study. It has been observed that the scale of teacher practices related to the stages of the reading process has two factors with an eigenvalue of more than 1. It was found that the scale is in a single-factor structure because the variant explained by two factors with eigenvalues above 1 is very low and the single-factor structure explains $70.19 \%$ of the total variance. According to Altunısık, Coşkun, \& Yıldırım (2010), factor load values of 0.21 are sufficient for sample size $\mathrm{n}=501$. Calculation of the factor loads of the Teacher Practices Scale Related to the Stages of the Reading Process (Yaratan, 2017), which consists of a single factor, between 0.570 and 0.728 , was evaluated as "very good" within the framework of these references.

Factor load value of .45 or higher is a good criterion for selection (Buyukozturk, 2012). To explain the structure, factor loads between .30 and .40 are generally considered as acceptable level loads. Loads of .50 and above are named as application-significant loads, and loads above .70 are defined as loads that can explain the structure well (Alpar, 2011). The fact that the adapted scale explains $70 \%$ of the total variance was interpreted as the contribution of a defining factor to the total variance of the scale.

Confirmatory factor analysis is often used in scale development and validity analyses and aims to verify a predetermined or fictitious structure (Bayram, 2013). In all sources related to DFA, RMSEA $\leq 0.05$; NFI $\geq .95$; CFI $\geq 0.90$; GFI; $\geq .90$; and the fact that $\mathrm{CMIN} / \mathrm{DF}=\mathrm{X} 2$ /sd $\leq 3$ shows good harmony (Bayram, 2013; Karagoz, 2016; Meydan $\&$ Sesen, 2015; Tabachnick \& Fidell, 2001). In the study, it was calculated that RMSEA $=.077, \mathrm{NFI}=.940, \mathrm{CFI}=.946$, $\mathrm{GFI}=.837$, and $\mathrm{CMIN} / \mathrm{DF}=3.708$. This shows that the scale of teacher practices related to the stages of the reading process has a perfect fit in terms of RMSEA, acceptable fit in terms of CMIN/DF, NFI, and CFI, and poor fit in terms of GFI. The Cronbach alpha coefficient of the Cronbach Alpha test results of the teacher practices scale related to the stages of the reading process was found to be 0.982 . According to Buyukozturk (2012), if the Cronbach Alpha reliability coefficient is above 0.70 , the measurement tool is reliable.

The second sub-problem of the study is "Do the practices related to the stages of the reading process used in the process of reading comprehension to students with mental disabilities differ according to the age of the teachers?" The answer to the question was sought. It was found that the difference between the scores of teachers covered by the study from the teacher practice scale related to the stages of the reading process according to the age group was not statistically significant $(\mathrm{p}>0.05)$. Although teacher practice scale scores for the stages of the reading process for teachers aged 35-39 years were higher than teachers in the other age group, the difference is not statistically significant. Regardless of age groups, it is seen that the scores the teachers got from the teacher practices scale regarding the stages of the reading process are close. As age progresses, teachers ' experiences increase. Consequently, it was thought that while doing reading activities with children, their desire to specialize more in the field they work in and the determination to teach were developed. Therefore, it is thought that this difference, which appears in teachers between the ages of 35 and 39 , is high compared to other age groups.

An answer was sought for the third sub-problem of the study, "Is there a difference in the learning of knowledge by the gender of the teachers in the reading and comprehension process of the student with intellectual disability?". It was observed that there was no statistically significant difference between the scores of the teachers included in the study from the teacher practices scale related to the stages of the reading process according to their gender. Although male teachers' scores on the scale of teacher practices related to the stages of the reading process are slightly higher than 
female teachers, they are not statistically significant. Topuzkanamıs and Maltepe (2010) also found that the success of reading comprehension in a study conducted on teacher candidates showed a significant difference in favour of female students by gender. Studies have shown that girls read more than boys. People who read more are expected to have a better level of reading comprehension. Information, suggestions, and practices regarding reading preferences and tendencies that may arise from individual differences such as age and gender, which have an important effect on students' acquisition of reading habits, are limited. Therefore, in this study, it is believed that male teachers score high points than female teachers may be due to individual differences.

The fourth sub-problem of the study is "Do the practices related to the stages of the reading process used in the process of reading comprehension to students with intellectual disabilities differ according to the educational level of the teachers?" The answer to the question was sought. It has been determined that the difference between the scores of the teachers who have received education at undergraduate and graduate levels from the teacher practice scale regarding the stages of the reading process is not statistically significant. $(\mathrm{p}>0.05)$. Although the scores of the teachers who received postgraduate education were found to be higher than the teachers with undergraduate education in the scale of practices related to the stages of the reading, the difference was not statistically significant. Beckman's study (2002) shows that learning strategies enable individuals to become lifelong literate and independent learners. It is believed that it is because of this reason that the scores received by teachers at the postgraduate level in the study were higher than those of undergraduate teachers. Besides, learning strategies make a contribution to students trusting in their thoughts, knowing that there is more than one way to do a job, realizing and correcting their own mistakes, assessing their learning and behaviour, strengthening their memory, increasing their learning level, knowing how to learn, improving their learning process and taking more responsibility in their learning (Topuzkanamis and Maltepe, 2010). Learning strategies that allow learners to become aware of their learning processes increase the effectiveness of the learning process. For this reason, it is believed that practices related to the stages of the reading process used in the process of reading comprehension can be effective as they specialize. It is an important and expected result that teachers who have developed reading skills also have a high academic success for counted reasons.

The fifth sub-problem of the study is "Do the practices related to the stages of the reading process used in the process of reading comprehension to students with intellectual disabilities differ according to the professional seniority of the teachers?" The answer to the question was sought. According to the professional seniority of teachers, it was found that the difference between teachers ' scores on the teacher practice scale related to the stages of the reading process was not statistically significant ( $>0.05$ ). Although the scores of teachers with professional seniority of 6-10 years on the Scale of Teacher Practices Related to the Stages of the Reading Process are high compared to other teachers, this difference is not statistically significant. Teachers were found to receive similar scores from the Scale of Teacher Practices Related to the Stages of the Reading Process regardless of their professional seniority. According to Akyol \& Temur (2008), reading development may vary depending on biological and environmental factors. The home environment is quite important for increasing reading success. There is a significant relationship between reading success and the environment and socioeconomic level offered to the student. For example, children of families with low socioeconomic levels have lower scores from oral expression and reading comprehension tests than children of medium-level families (Coskun, 2003). The success explained by the socio-economic level is related to subjecting the student to some educational activities. For instance, a visit to a museum, a visit to libraries, a trip to the zoo, and collecting information about animals are educational activities that contribute to the student's school success. Apart from environmental factors, biological and neurological factors that affect teaching reading are also important. These factors are estimated to affect $2-15 \%$ of students' success in reading. It was thought that the fact that the scores of teachers obtained from the teacher practice scale regarding the stages of the reading process according to their professional seniority were not statistically significant, might be related to the fact that the student groups teachers work with have similar socioeconomic characteristics.

The sixth sub-problem of the study is "Do the practices related to the stages of the reading process used in the process of reading comprehension to students with intellectual disabilities differ according to the class size of the teachers?" The answer to the question was sought. It was observed that there was no statistically significant difference between the total scores of teachers who were included in the study of the Scale of Teacher Practices Related to the Stages of the Reading Process according to the classroom size in which they work $(\mathrm{p}>0.05)$. Teachers with a class presence of 5-8 students scored lower on the Scale of Teacher Practices Related to the Stages of the Reading Process than other teachers, but this difference is not statistically significant. The fact that teachers with a class size of 5-8 students got lower scores than other teachers on the Scale of Teacher Practices Related to the Stages of the Reading Process (Akyol \& Temur, 2008), may because of teachers' individual differences, different teaching methods and techniques they used, and the equipment of their schools have affected these results. Also, it is thought that the large class size and the poor attention span of the students are also important factors. 


\section{References}

Akbayır, S. (2003). Cumle ve metin bilgisi. Samsun: Deniz Kultur Yayınları.

Akcamete, G., \& Gokbulut, O. D. (2018). Opinions of classroom teachers on reading comprehension difficulties, inclusion education and co-teaching. Quality \& Quantity, 52(1), 791-806. https://doi.org/10.1007/s11135-017-0664-7

Akyol, H., \& Temur, T. (2008). Ses temelli cumle yontemi ve cumle yontemi ile okuma yazma ogrenen ogrencilerin okuma becerilerinin ogretmen goruslerine gore degerlendirilmesi. Mustafa Kemal Universitesi Sosyal Bilimler Enstitusu Dergisi, 5(9), 79-95.

Akyol, H., Çakıroglu, A., \& Kuruyer, H. G. (2014). A study on the development of reading skills of the students having difficulty in reading: Enrichment reading program. International Electronic Journal of Elementary Education, 6(2), 199-212.

Alpar, R. (2011). Applied multivariate statistical methods. Ankara: Detay, 10-29.

Altunısık, R., Coskun, R., Bayraktaroglu, S., \& Yıldırım, E. (2010). Sosyal bilimlerde arastırma yontemleri: SPSS uygulamalı. Sakarya yayıncılık.

Baştug, M., \& Akyol, H. (2012). Akıcı okuma becerilerinin okudugunu anlamayı yordama duzeyi. Kuramsal Egitim Bilim Dergisi, 5(4), 394-411.

Bayram, N. (2013). Yapısal eşitlik modellemesine giriş. Bursa: Ezgi Kitabevi.

Beckman, P. (2002). Strategy Instruction, Clearinghouse on Disabilities and Gifted Education, (ED474302), (Retrieved on 31.12.2019 from the ERIC Database Internet address.).

Brown, G. T. (2006). Teachers' conceptions of assessment: Validation of an abridged version. Psychological reports, 99(1), 166-170. https://doi.org/10.2466/pr0.99.1.166-170

Bursuck, W., \& Damer, M. (2007). Reading instruction for students who are at risk or have disabilities. Boston: Allyn \& Bacon.

Buyukozturk, S. (2009). Sosyal bilimler icin veri analizi el kitabı. (10. Bask1) Ankara: Pegem A Akademi.

Buyukozturk, S., Kılıc Cakmak, E., Akgun, E. A., Karadeniz, S., \& Demirel, F. (2012). Bilimsel Arastırma Yontemleri (11. Baskl). Ankara: Pegem Yayınları.

Cetinkaya, N. (2018). Hikaye haritast yonteminin video geri bildirim ile sunumunun zihin yetersizligi olan cocukların okudugunu anlama becerisindeki etkililigi (Yayımlanmamıs yuksek lisans tezi). Abant İzzet Baysal Universitesi, Egitim Bilimleri Enstitusu, Ozel Egitim ABD, Bolu.

Coskun, A. G. E. (2003). Cesitli degiskenlere gore lise ogrencilerinin etkili okuma becerileri ve bazı oneriler. Turkluk Bilimi Arastırmalarl, (13), 101.

Cuhadar, F. (2012). Mesleki egitim merkezindeki turkce derslerinde uygulanan sessiz okuma etkinligi ile sessiz okuma anında yapılan dinlenme etkinliginin ögrencilerin okuma becerisi etkisinin karsılastırılması. (Yayımlanmamıs yuksek lisans tezi). Necmettin Erbakan Universitesi Egitim Bilimleri Enstitusu, Konya.

Erkorkmaz, U., Etikan, I., Demir, O., Ozdamar, K., \& Sanisoglu, S. Y. (2013). Confirmatory factor analysis and fit indices: Review. Turkiye Klinikleri J Med Sci, 33(1), 210-23. https://doi.org/10.5336/medsci.2011-26747

Gokbulut, O. (2018). Ozel gereksinimli ögrencilerin okudugunu anlama becerilerinin gelistirilmesinde birlikte ogretim yaklasımının etkililiginin degerlendirilmesi (Yayımlanmamıs yuksek lisans tezi). Yakın Dogu Universitesi, Egitim Bilimleri Enstitusu, Ozel Egitim Anabilim Dalı, Lefkosa.

Guzel, R. (1998). Alt ozel sinıflardaki ogrencilerin sesli okuduklarl oykuyu anlama becerilerini kazanmalarında dogrudan ogretim yontemiyle sunulan bireysellestirilmis okudugunu anlama materyalinin etkililigi (Yayınlanmamis doktora tezi). Gazi Universitesi, Ankara.

Kanmaz, A. (2012). Okudugunu anlama stratejisi kullanımının, okudugunu anlama becerisi, bilissel farkındalık, okumaya yonelik tutum ve kalıcılı̆̆a etkisi (Doktora Tezi). Adnan Menderes Universitesi, Sosyal Bilimler Enstitusu, Egitim Bilimleri Anabilim Dalı, Aydın.

Karagoz, Y. (2016). SPSS ve AMOS 23 uygulamaları. Ankara: Nobel Yayıncılık.

Karasar, N. (2013). Bilimsel arastırma yöntemi. Ankara: Nobel Yayınevi.

Klein, M. L. (1988). Teaching reading comprehension and vocabulary. A guide forteachers. New Jersey: Prentice - Hall. Kolstoe, O.P. (1976). Teaching Educable Retarded Children. New York: Holt, Rinehart\& Winston, Inc. York: 
Guilford Press, 154-186.

Kline, T. J. (2005). Psychological testing: A practical approach to design and evaluation. Sage Publications. https://doi.org/10.4135/9781483385693

Meydan, C. H., \& Sesen, H. (2015). Yapısal esitlik modellemesi. Ankara: Detay Yayıncılık.

NRP, (2000). Teaching children to read: An evidence-based assessment of the scientific research literature on reading and its implications for reading instruction. Washington, DC: National Institute of Child Health and Human Development.

Oakhill, J., Yuill, N., \& Garnham, A. (2011). The differential relations between verbal, numerical and spatial working memory abilities and children's reading comprehension. International Electronic Journal of Elementary Education, 4(1), 83-106.

Ozbay, M., \& Ozdemir, B. (2012). Okudugunu anlama surecinde cıkarım yapma becerisinin işlevi. Mustafa Kemal Universitesi Sosyal Bilimler Enstitusu Dergisi, 9 (18), 17-28.

Ozdamar, K. (2002). Paket Programları ile Istatistiksel Veri Analizi (Çok Degiskenli Analizler) 2, 4. Baskı, Eskisehir.

Ozmen, R. G. (2011). Zihinsel yetersizligi olan ogrencilerin bilgi veren metinlerdeki bilgileri hatırlamalarında sematik duzenleyicilerin iki farklı sunum seklinin karsılastırılması. Kuram ve Uygulamada Egitim Bilimleri, 11(2), 773-793.

Polloway, E. A., Patton, J. R., \& Serna, L. (2014). Strategies for teaching learners with special needs, ozel gereksinimi olan ogrenciler icin ogretim stratejileri. SY Ozkan (Çev. Ed.).(10. Basımdan Çeviri). Ankara: Nobel Akademik Yaylncillk.

Sever, S. (1997). Turkce Ogretimi ve Tam Ogrenme. Ankara: Anı Yayınc1lı.

Sumer, N. (2000). Yapısal Esitlik Modelleri: Temel Kavramlar ve Ornek Uygulamalar. Turk Psikoloji Yazllarl, 3(6) 49-74.

Tabachnick, B. G., \& Fidell, L. S. (2013). Using Multivariate Statistics, 6th Edn. Northridge. CA: California State University.

Topuzkanamıs, E., \& Maltepe, S. (2010). Ogretmen adaylarının okudugunu anlama ve okuma stratejilerini kullanma duzeyleri. Tubar -27, 655-677.

Uysal, P. K., \& Bilge, H. (2019). An investigation on the relationship between reading fluency and level of reading comprehension according to the type of texts. International Electronic Journal of Elementary Education, 11(2), 161-172. https://doi.org/10.26822/iejee.2019248590

Vaughn, S., \& Klingner, J. (2004). Teaching Students with Reading Comprehension to Students with Learning Disabilities. In Handbook Of Language and Literacy. C. A. Stone, E. R. Silliman, B J. Ehren, and K. Apel (Editors). NewYork: The Guilford Press.

Yaratan, H. (2017). Sosyal Bilimler Icin Temel İstatistik SPSS Uygulamalı. Ankara: Anı Yayınc1lık.

Yıldırım, A., \& Simsek, H. (2006). Qualitative research methods in social sciences. Ankara: Seckin Publications.

Zarain, X. U. (2007). Growth mixture modeling with a distal outcome: an application toreading and high stakes testing. (Unpublished doctoral dissertion). University of Delaware, Newark, USA.

\section{Copyrights}

Copyright for this article is retained by the author(s), with first publication rights granted to the journal.

This is an open-access article distributed under the terms and conditions of the Creative Commons Attribution license which permits unrestricted use, distribution, and reproduction in any medium, provided the original work is properly cited. 